\title{
Wearing of a Whole-Body Compression Garment Can Enhance Exercise Efficiency
}

\author{
Su-Jeong Jeon ${ }^{1, *}$, Yu-Jin Jung ${ }^{1, *}$, Eun-Jae Lee ${ }^{1, *}$, Ji-Hye Choi ${ }^{1, *}$ and Dongju Jung ${ }^{1,2, ;, * *}$ \\ ${ }^{1}$ Department of Biomedical Laboratory Science, College of Life and Health Sciences, \\ Hoseo University, Asan, Chungnam 31499, Korea \\ ${ }^{2}$ The Research Institute for Basic Sciences, Hoseo University, Asan, Chungnam 31499, Korea
}

\begin{abstract}
A whole-body compression garment (WBCG) is mainly used for cosmetic purpose in Korea. Another case for wearing the WBCG would be while exercising because it allows the body to move easily. But physiological effects of wearing WBCG to the body have not been known much. To investigate whether wearing WBCG would be helpful for conducting exercises, we measured physiological criteria, which could be influenced by the compression, such as cardiovascular and pulmonary function. Twelve female college students participated in this experiment. Increase of blood pressure was monitored in all of the participants when they wore a WBCG just for 10 minutes. Pulmonary function that requires skeletal muscle contraction was decreased by wearing a WBCG. Blood pressure measured after conducting exercise became even lower when wearing a WBCG than non-wearing. Interestingly, heart pulse remained lower when wearing a WBCG than non-wearing during the whole relaxing period after the exercise. Electrocardiogram (ECG) analyses showed that such lower heart rate largely depended on extension of QT time. For that reason, physiological efficiency index (PEI) was higher for wearing WBCG. These results indicate wearing WBCG could enhance exercise efficiency by lowering heart pulse.
\end{abstract}

Key Words: Whole-body compression garment (WBCG), Blood pressure, Pulmonary function

\section{서 론}

보정속옷(whole-body compression garment)은 체지방으 로 인해 느슨해진 몸의 굴곡을 교정하고자 주로 여성들 이 착용하는 의류로 오래전부터 사용되어 왔고 최근에는 다리의 근력 증강이나 통증완화를 위한 목적으로도 사용 된다(MacRae et al., 2011; da Silva et al., 2018). 보정속옷보다 낮은 압박 강도의 소재는 주로 운동용 의류를 제작하는 데 이용되고 있다. 이 중 인기를 그는 것으로는 레깅스를 들 수 있으며 이제는 남녀 모두 운동 시에 착용하는 비
율이 높아지고 있다. 계속적인 의류 소재의 개발로 인해 과거에 비해 얇으면서도 압박 강도가 강한 다양한 제품들 이 나오면서 운동효과뿐만 아니라 몸매 교정의 목적으로 시중에서 판매되고 있다. 그래서 이제는 몸매 교정을 위 한 보정속옷과 운동을 위한 의류에 소재나 압박 강도에 큰 차이가 없게 되었다. 몸을 압박하는 강도가 높은 의류 의 착용은 운동에 도움이 된다고 알려져 있다(Pribis et al., 2010; Chan et al., 2016). 한 예로 압박 강도가 $15 \mathrm{mmHg}$ 이상 되는 의류를 착용하고 언덕을 달려 올라가는 운동 을 수행했을 경우, 운동 후 빠른 회복에 도움이 되는 것 으로 보고되었다(Struhar et al., 2018). 압박 강도가 강할

Received: June 8, 2021 / Revised: June 22, 2021 / Accepted: June 25, 2021

*Undergraduate student, ${ }^{* *}$ Professor.

${ }^{\dagger}$ Corresponding author: Dongju Jung. Department of Biomedical Laboratory Science, College of Life and Health Sciences, Hoseo University, Asan, Chungnam 31499, Korea.

Tel: +82-41-540-9969, Fax:+82-41-540-9997, e-mail: djjungg@hoseo.edu

(C) The Korean Society for Biomedical Laboratory Sciences. All rights reserved.

(c) This is an Open Access article distributed under the terms of the Creative Commons Attribution Non-Commercial License (http://creativecommons.org/licenses/by-nc/3.0/) which permits unrestricted non-commercial use, distribution, and reproduction in any medium, provided the original work is properly cited. 
수록 체형 보정효과는 증가하지만 운동효과는 어느 정 도 압박 이상에서는 증가하지 않는 것으로 알려져 있다 (Struhar et al., 2018). 하지를 압박하는 압박스타킹의 경우 는 운동 후 발생하는 근육통증의 감소나 부종에는 효과 가 없는 것으로 보고되었다(Heiss et al., 2018). 최근에 국 내에서 판매 중인 보정속옷은 과거 보정속옷과 달리 움 직임에 불편함을 주지 않으며, 높은 압박 강도를 제공하 므로 이러한 보정속옷이 운동에도 효과적인지 조사하게 되었다. 이번 실험에서는 시중에서 판매되는 압박용 의류 중에서 몸 전체를 압박하는 보정속옷을 착용 시 몸의 생 리적 기능에 어떤 영향을 미치는지 실험을 통해 확인하 였다. 운동용 압박 의류는 레깅스와 같이 다리에 착용하 는 것이 주로 이용되고 있고 이러한 제품들은 상체를 압 박하지 않기 때문에 몸의 생리기능 중 혈압과 폐기능에 대해서는 관련성이 크지 않았다. 하지만 상체부위까지 압 박하는 보정속옷이 시중에 많이 나와있고, 점차 이용이 증가되고 있으므로 상체부위를 포함한 몸 전체를 압박하 는 것이 혈압과 폐기능에 어떤 영향을 미치는지 조사하 는 것이 의미가 있다고 판단하였다. 이번 실험에 사용된 보정속옷의 압박 강도는 $24 \mathrm{hPa}(18 \mathrm{mmHg})$ 정도였으며, 이는 기존에 보고된 높은 운동효율을 나타내는 운동용 의 류의 압박 강도와 유사한 수준이었다. 보정속옷의 주된 사용자가 여성이기 때문에 20대 여성에서의 생리 변화를 측정하였다. 심혈관계 관련 지표로는 혈압과 맥박을 측정 하였고, 폐기능 검사로는 잔기량(residual volume, RV)을 제 외한 폐활량 관련 검사를 수행하였다. 혈압과 맥박의 변 화를 분석하기 위해 심전도를 이용하여 파형간 시간을 측 정하였다. 이 실험을 통해 보정속옷 착용이 골격근의 압 박을 통해 일상생활에서 미치는 영향과, 운동 시 어떤 영 향을 미치는지 확인하였다.

\section{재료 및 방법}

\section{보정속옷(Compressing garment)}

보정속옷은 FLASEEK 사의 '플레시크 시크릿 캐미솔' $\mathrm{S}$ (55-77) 사이즈 제품을 구매하여 사용하였다. 이 제품은 여성의 몸매보정을 위한 목적으로 만들어졌으며 몸의 굴 곡에 따라 모든 부위를 압박할 수 있도록 재단되어 특정 한 부위에 압력이 가해지는 것이 아니라 착용한 몸의 전 부위에 고른 압박을 나타내는 것으로 표시되어 있다. 압 박부위는 상의의 경우 목, 가슴부위 및 팔을 제외한 상체 전체이고, 하의의 경우 발목 이하 부분을 제외한 하체 전
체를 압박한다. 압박 정도는 제조사 기준 8 F.S.P (Flaseek Seekret Point) 이상의 압박보정 강도를 가지며 이는 $24 \mathrm{hPa}$ $(18 \mathrm{mmHg})$ 이상의 압력을 보장한다. 이 수준의 압박보정 강도는 착용 시 살이 바깥으로 드러나지 않을 정도의 강 한 압축효과를 나타냈으며 착용자는 압박감을 충분히 느 낄 정도였으며 착용 전과 비교하여 혈압도 상승하였다. 보정속옷 착용과 관련된 모든 실험은 호서대학교 생명윤 리위원회의 기준을 준수하여 실행하였다.

\section{체지방 측정}

몸의 근육량 및 지방량의 측정은 인바디사의 S-10 수분 측정기를 이용하였다. 이 제품은 몸의 각 부위별로 체지 방 측정이 가능하여 제조사에서 제시한 방법대로 신체의 각 부위에 전극을 부착하여 해당 지표들을 측정하였다.

\section{혈압 및 맥박 측정(Measuring blood pressure and pulse)}

혈압과 맥박은 자동혈압측정계(Omron Healthcare Co.)를 이용하여 상완에서 측정하였다. 각 측정 시마다 2회씩 반 복 측정하여 두 수치간 큰 차이가 발생하지 않을 경우 측정치로 사용하였다.

\section{폐기능 검사(Pulmonary function test)}

폐기능 검사의 모든 실험은 SensorMedics 사의 $\operatorname{Vmax} 20$ 제품을 이용하여 잔기량(residual volume, RV)을 포함하지 않는 폐활량 지표들을 측정하였다. 이 지표들은 노력성 폐활량(Forced Vital Capacity, FVC), 1초량(Forced Expiratory Volume 1 second, FEV1), 1초율(FEV1/FVC $\times 100)$, 노력성 날숨중간유량(Forced Expiratory Flow 25 75\%, FEF 25 $75 \%$ ), 최대호기유속(Peak Expiratory Flow, PEF), 최대환기 량(Maximal Voluntary Ventilation, MVV)이다. 운동부하 후 측정 시에는 운동을 마친 뒤 편한 자세에서 바로 측정을 하였다.

\section{심전도 검사(Electrocardiogram measurement)}

심전도는 편하게 누운 상태에서 표준 12 유도법을 이용 하여 측정하였다. 심전계는 $\mathrm{GE}$ 사의 $\mathrm{MAC} 2000$ 장비를 이용하였다. 심전도 파형의 구간별 시간은 심전계에서 측 정 후 나타나는 결과를 이용하였고, 결과 중 일부를 수작 업으로 계산하여 심전계에서 나타나는 결과에 문제가 있 는지를 확인하였다. 운동부하 후 측정 시에는 운동을 마 친 뒤 편하게 누운 상태에서 바로 측정을 하였다. 


\section{운동부하방법(Exercise test)}

운동부하를 가하기 위한 방법으로 학생건강체력평가 (physical Activity Promotion System, PAPS)에서 제안하는 스텝검사를 이용하였다. $50 \mathrm{~cm}$ 의 스텝 박스를 분당 30 회 로 5 분간 오르내리기를 실시하고 이후 일정 시간 간격에 따라 혈압, 심박수, 심전도, 폐기능에 대한 검사를 실시하 였다. 심박수를 이용해 신체효율지수(Physical Efficiency Index, PEI)를 다음과 같이 측정하였다.

$$
\text { 신체효율지수 }(\mathrm{PEI})=\frac{\text { 운동지속시간(초 }) \times 100}{2 \times \text { (회복 시 } 3 \text { 회 측정한 심박수의 합 })}
$$

\section{통계처리}

보정속옷 착용에 따른 변화를 보기 위해 착용 전과 착 용 후의 비교는 대응표본(paired) $t$-test를 이용하여 비교하 였다. $\mathrm{n}<30$ 이므로 Shapiro-Wilk Test를 통해 정규성을 검 증하였다. 검증은 Statistics Kingdom 사이트에서 제공하는 calculator를 통해 실시하였고, $t$-test를 실시하기 전 모두 정규성 검증을 하였다. $P$ 값에 따라 매우 큰 차이 $(P<$ $0.01)$, 의미 있는 차이 $(P<0.05)$ 그리고 차이 없음 $(P>0.05)$ 으로 나타냈다.

\section{결 과}

이 실험에 참가한 참가자의 키, 몸무게, 혈압 및 체지
방량 등에 대한 신체 지표는 Table 1에 나타냈다. 참가자 들은 대학교에 재학 중인 여학생들로 모두 동일한 나이 였으며 다른 신체 지수에서도 큰 차이를 나타내지 않았 다. 모든 참가자는 기저 질환이 없는 양호한 건강 상태였 고, 혈압 관련 질환이나 호흡기 질환을 최근에 겪은 일이 없었다. 참가자들의 골격근량(SMM), 체지방량(Body Fat) 그리고 체지방률(PBF)은 성인 여성의 평균치와 크게 다 르지 않았다(Pribis et al., 2010). 인바디로 측정한 근육량은 최소 $19.5 \mathrm{~kg}$ 에서 최대 $22.4 \mathrm{~kg}$ 사이의 범위였고, 체지방은 최소 $19.3 \mathrm{~kg}$ 에서 최대 $28.9 \mathrm{~kg}$ 사이의 범위에 해당하였다. 이에 따른 체지방률은 $28.4 \%$ 에서 $40.8 \%$ 까지 범위에 해당 하였으며 이는 통계청에서 제시한 대한민국 20 대 여성의 평균적인 체지방률과도 유사하였다.

참가자들이 보정속옷을 착용한 뒤 혈압이 어떻게 변화 하는지 확인하였다. 보정속옷은 상하로 나뉘어 한 벌로 구성되어 있다. 상의는 가슴부위와 팔을 제외한 나머지 상 체를 커버하며, 하의는 발목 이하를 제외한 나머지 하체 를 커버한다(Fig. 1). 수축기혈압의 수치는 개인별로 차이 가 있었으나, 보정속옷을 착용한 뒤 10 분 정도면 혈압이 착용 전에 비해 $10 \%$ 정도 상승하는 것을 모든 참가자에 서 공통적으로 확인할 수 있었다. 보정속옷 착용 직후 상 승된 혈압은 착용하고 있던 12시간 동안 계속 상승된 상 태로 유지되었고, 보정속옷을 벗을 경우 10 분 만에 모두 착용 전 수치로 떨어진 것으로 나타났다(Fig. $2 \mathrm{~A}$ ). 착용 전 수치로 떨어진 혈압은 다시 상승하지 않음을 30 분 뒤에 측정된 혈압을 통해 확인할 수 있었다. 보정속옷 착용은

Table 1. Biological profiles of the participants

\begin{tabular}{|c|c|c|c|c|c|c|}
\hline & Height $(\mathrm{cm})$ & Weigh $(\mathrm{kg})$ & Age (year) & $\operatorname{SMM}(\mathrm{kg})$ & Body fat $(\mathrm{kg})$ & PBF (\%) \\
\hline 1. Jung ${ }^{*}$ & 159 & 51 & 23 & 20 & 19.3 & 28.4 \\
\hline 2. $\mathrm{Kim}^{*}$ & 160 & 51 & 23 & 19.5 & 18.6 & 27.9 \\
\hline 3. Lee $^{*}$ & 155 & 56 & 23 & 20 & 19.9 & 34.5 \\
\hline 4. Choi ${ }^{*}$ & 166 & 70 & 23 & 22.2 & 28.6 & 40.8 \\
\hline 5. Jeon ${ }^{*}$ & 165 & 55 & 23 & 20.1 & 20.2 & 35.4 \\
\hline 6. Kang ${ }^{*}$ & 154 & 56 & 23 & 20.2 & 19.7 & 34.2 \\
\hline 7. $\mathrm{Kim}^{* *}$ & 165 & 68 & 23 & 22.3 & 28.9 & 41 \\
\hline 8. Lee ${ }^{* *}$ & 164 & 53 & 23 & 19.9 & 20.3 & 35.8 \\
\hline 9. Jang ${ }^{*}$ & 159 & 52 & 23 & 20.3 & 19.5 & 28.7 \\
\hline 10. Cho ${ }^{*}$ & 166 & 56 & 23 & 20.2 & 20.4 & 35.3 \\
\hline 11. Hyun ${ }^{*}$ & 155 & 55 & 23 & 20.1 & 20.1 & 34.7 \\
\hline 12. Hong ${ }^{*}$ & 167 & 70 & 23 & 22.4 & 28.7 & 40.2 \\
\hline
\end{tabular}

Abbreviations: SMM, Skeletal Muscle Mass; PBF, Percent Body Fat 
12 명 참가자 전원에게 모두 동일한 혈압 상승효과를 나 타냈고 이를 통해 보정속옷의 착용은 $10 \%$ 정도의 혈압 상승효과를 일으킬 수 있음을 알게 되었다. 장시간 보정 속옷 착용이 폐기능과 운동부하에 어떤 영향을 미치는지 확인하기 위해 이번 실험에서 가장 장시간 착용한 12 시 간 착용 시의 혈압과 맥박의 변화를 확인하였다. 12 시간 착용은 수축기혈압과 이완기혈압 모두를 상승시키는 결 과를 나타냈다(Fig. 2B). 혈압의 상승은 수축기 이완기 모 두 통계적으로 매우 높은 수준의 상승을 나타냈고 $(P<$ $0.01)$, 맥박의 상승도 통계적으로 의미 있는 상승이 나타
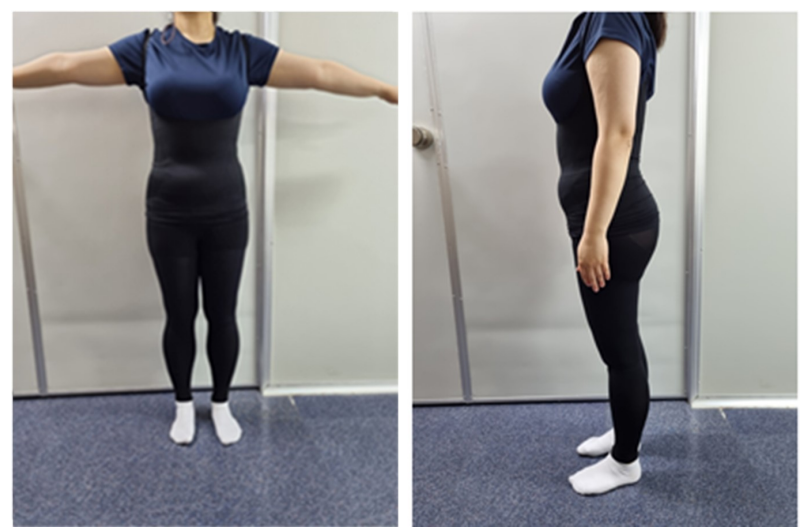

Fig. 1. Wearing of the compression garment. The compression garment composed of two pieces. One for covering upper body, the other for covering hip and legs. The arms and breast are not covered.
났다 $(P<0.05)$. 즉 혈압의 상승과 맥박의 상승 모두 보정 속옷 12 시간 착용에 의해 증가함을 확인할 수 있었고 이 렇게 혈압과 맥박이 상승한 상태에서 폐기능 검사와 운 동부하 검사를 수행하였다.

폐기능검사는 노력성폐활량(FVC), 1초량(FEV1), 1초율 (FEV1/FVC), 노력성날숨중간유량(FEF 25 75\%), 최대호

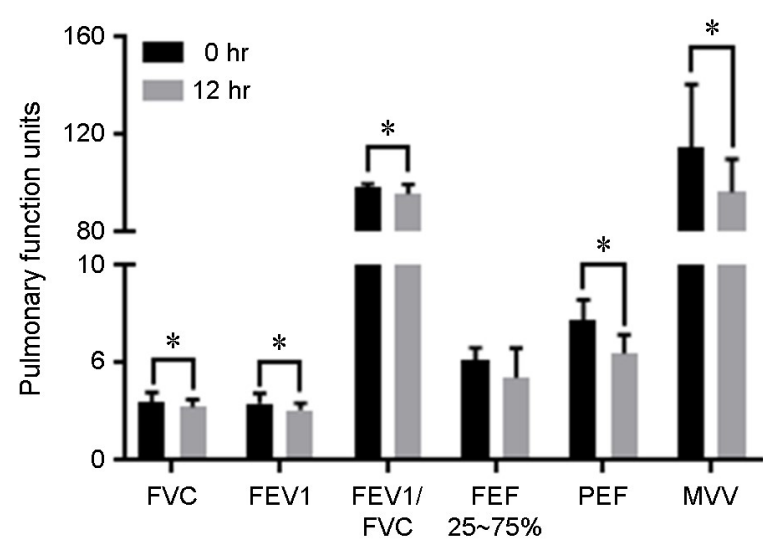

Fig. 3. Effects of the compression garment to pulmonary function. Unit for FVC and FEV1 is liter (L). FEV1/FVC indicates percentile ratio of FEV1 to FVC. Unit for FEF $25 \sim 75 \%$ and PEF is liter per second $(\mathrm{L} / \mathrm{sec})$. Unit for MVV is liter per minute (L/min). Abbreviations: FVC, Forced Vital Capacity; FEV1, Forced Expiratory Volume in one second; FEF 25 75\%, Forced Expiratory Flow 25 75\%; PEF, Peak Expiratory Flow; MVV, Maximal Voluntary Ventilation. Data shown represent the mean $\pm \mathrm{SD}(*$ indicates $P<$ $0.01)$.

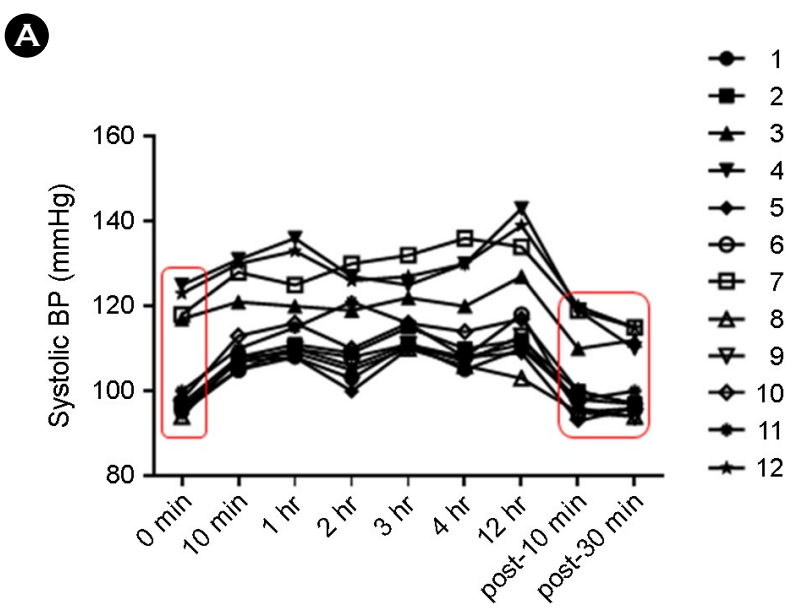

B

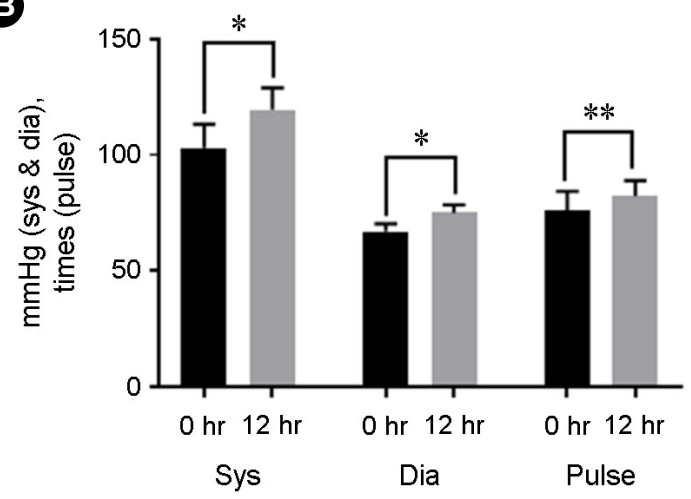

Fig. 2. Effects of the compression garment to blood pressure and heart pulse. Blood pressure and heart pulse of the twelve participants were measured with or without wearing the compression garment. (A) Systolic blood pressure was measured at the time since wearing the compression garment. Red squares indicate the period of not wearing the compression garment. (B) Blood pressures and heart pulse were measured to compare the difference before and after wearing the compression garment. Abbreviations: Sys, systolic blood pressure; Dia, diastolic blood pressure. Data shown represent the mean $\pm \mathrm{SD}$ (*indicates $P<0.01$, **indicate $P<0.05$ ). 
기유속(PEF), 최대환기량(MVV)을 측정하였다. 보정속옷 을 12 시간 착용한 상태에서 측정된 폐기능은 착용 전에 비해 대부분의 검사에서 낮아진 검사 수치를 나타냈다. $\mathrm{FVC}, \mathrm{FEV} 1, \mathrm{FEV} 1 / \mathrm{FVC}, \mathrm{PEF}, \mathrm{MVV}$ 등의 검사에서는 모두 통계 분석을 통해 매우 큰 차이로 보정속옷 착용 시 수 치가 감소한 것으로 측정되었다. 노력과 상관없는 폐 자 체의 기능을 나타내는 FEF $25 \sim 75 \%$ 수치는 통계적으로 차이가 없는 것으로 나타났다. 즉 폐기능 검사를 실시하 여 보정속옷의 착용이 어느 정도 폐기능에 영향을 미치 는지 확인해본 결과 노력성폐활량과 관련된 수치가 모두 감소하는 결과를 얻었고 폐 자체의 호흡에는 영향이 없 는 것으로 나타났다. 이 결과는 보정속옷의 착용은 노력

\section{A}

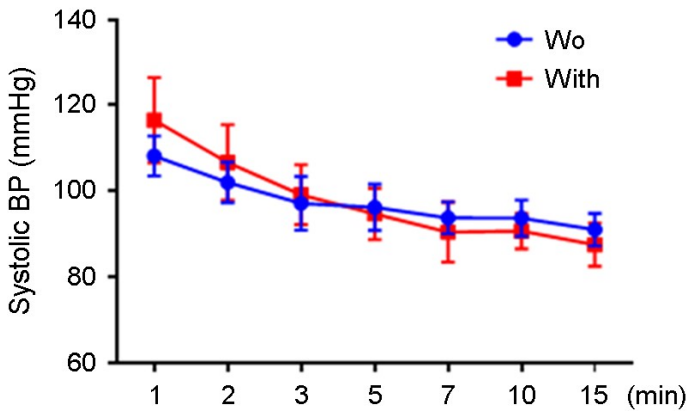

C

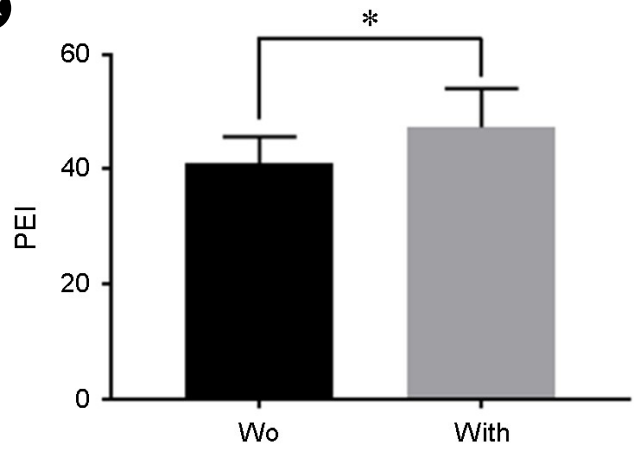

성 호흡을 위해 필요한 골격근의 압박에만 영향이 있는 것으로 나타났고, 갈비뼈로 둘러싸인 폐는 압박되지 않았 음을 나타냈다(Fig. 3).

안정된 상태에서의 효과를 확인한 이후, 운동을 실시했 을 경우 보정속옷 착용이 혈압과 맥박에 미치는 영향을 알아보고자 보정속옷 착용 전과 12 시간 착용 후 각각 정 해진 운동량을 실시하고 혈압과 맥박의 변화를 확인해보 았다. 운동 실시 후 측정한 수축기혈압은 안정된 상태와 같이 보정속옷을 착용했을 경우 착용 전과 비교하여 혈 압이 $10 \%$ 정도 상승되어 있는 것을 확인할 수 있었다. 하지만 운동이 끝나고 시간이 지날수록 보정속옷 착용 시는 혈압이 더 빠르게 떨어져서 5 분이 지난 뒤는 착용

B

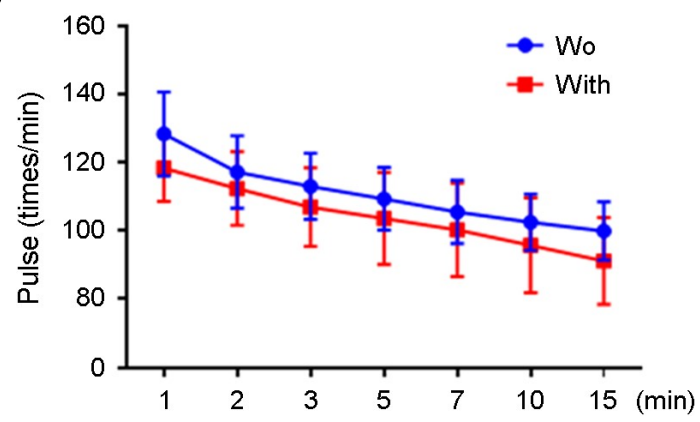

Fig. 4. Change of blood pressure and heart pulse after finishing the exercise. (A) Systolic blood pressure was measured at the time point after finishing the exercise. (B) Heart pulse was measured at the time point after finishing the exercise. (C) Based on the data of heart pulse as shown on B, PEI (Physical Efficiency Index) was calculated. Wo and With indicate without wearing and wearing the compression garment, respectively. Data shown represent the mean $\pm \mathrm{SD}(*$ indicates $P<0.01)$.

Table 2. Comparisons of the intervals on the Electrocardiogram (ECG)

\begin{tabular}{lccccc}
\hline \hline & $\mathrm{P}$ & $\mathrm{PR}$ & $\mathrm{QRS}$ & $\mathrm{QTc}$ & $\mathrm{RR}$ \\
\hline $\begin{array}{l}\text { Non-wearing } \\
(\mathrm{msec})\end{array}$ & $97 \pm 5.4$ & $145 \pm 10.3$ & $88 \pm 5.8$ & $435 \pm 12.3$ & $599 \pm 47.3$ \\
$\begin{array}{l}\text { Wearing } \\
\text { (msec) }\end{array}$ & $95 \pm 11.5$ & $145 \pm 13.2$ & $87 \pm 5.4$ & $446 \pm 9.9$ & $612 \pm 40.8$ \\
\hline
\end{tabular}
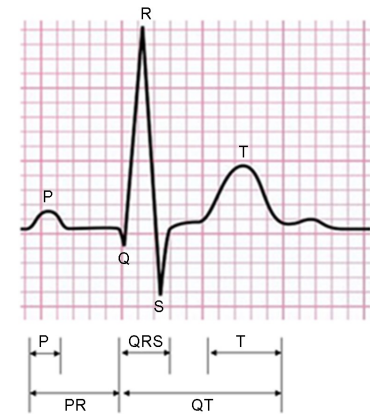
전과 비교하여 혈압이 오히려 감소한 결과가 나타났다 (Fig. 4A). 운동 후 맥박은 착용 전 상태가 높았으며 이후 운동을 멈추고 휴식을 취하는 15 분의 시간에서도 계속 착용 후 보다 더 높은 상태를 유지하였다(Fig. 4B). 운동 후 측정된 심박수를 이용하여 신체효율지수(PEI)를 계산 해본 결과 보정속옷을 착용한 경우 통계적으로 큰 차이 가 있는 정도로 $(P<0.01)$ 효율이 높아진 것을 확인할 수 있었다(Fig. 4C).

보정속옷 착용이 운동부하에 따른 혈압의 상승을 유발 하나 맥박의 증가는 유발하지 못하므로 우리는 심전도를 이용하여 심장의 전도 계통 과정 중 보정속옷 착용에 의 해 영향을 받는 구간을 확인하였다. 보정속옷 착용 상태 에서 운동을 실시한 뒤 측정된 심전도 결과는 QT 시간이 보정속옷 착용 전에 비해 증가된 것으로 나타났다(Table 2). 동시에 측정된 다른 심전도 파형의 시간에는 보정속 옷 착용 유무에 따른 차이가 나타나지 않았다. 이 결과는 보정속옷 착용 시 심박수가 착용 전에 비해 증가하지 않 은 이유가 QT 간격의 증가에 의해 일어난 것을 나타낸다.

\section{고 찰}

이번 실험에서는 높은 압박 강도를 가진 보정속옷이 평상 시와 운동 시 인체에 어떤 영향을 미치는지 분석하 였다. 보정속옷은 형태나 기능에서 일반적인 운동용 스포 츠웨어와 차이가 있었지만 최근에는 섬유소재의 개발로 인해 착용감이 좋으면서도 보정기능이 뛰어난 제품들이 많이 출시되고 있어서 보정속옷과 운동복의 경계가 허물 어졌다고 볼 수 있게 되었다. 특히 보정속옷은 상체 또 한 압박하게 되므로 그동안 하체에 착용하는 운동복으로 측정되었던 생리 상태 변화와 같은 운동생리부분에 대해 서는 연구가 자세히 이루어지지 않았다. 이번 실험에서는 상체와 하체를 모두 상당한 정도로 압박하는 보정속옷을 착용하고 운동 전과 후의 생체 지표를 비교 분석함으로 써 몸 전체를 압박하는 보정속옷이 가진 운동효율 증가 에 대한 효과를 확인하였다. 보정속옷은 착용 직후 혈압 을 $10 \%$ 상승시키는 효과를 나타냈는데 이는 다리를 압 박하는 운동용 압박 레깅스에서도 확인되었듯이 인체의 혈액이 다리나 복강 내에 머물지 못하도록 압박함으로써 순환이 증가된 효과로 판단된다(Privett et al., 2010).

인간의 신체는 체중을 기준으로 체지방량(fat mass)과 체지방을 제외한 나머지 부분으로 나눠볼 수 있다. 체지 방을 제외한 부분은 단백질 및 수분과 무기질이 합해
진 양으로 구성된다. 이중 단백질과 수분을 합쳐 근육량 (muscle mass)으로 나타낸다. 여성과 남성의 경우는 차이 가 있어서 여성은 체지방량(fat mass)이 높고, 남성은 근 육량(muscle mass)가 높은 것으로 알려져 있다(Abe et al., 2003; Karastergiou et al., 2012). 실험에 참여한 참가자들은 모두 여성이었으며 보정속옷의 착용 전후 인바디로 측정 된 체지방량과 근육량에는 변화가 없었다(Data not shown). 이는 압박을 받을 경우 근육과 지방의 위치 변화는 있을 지 언정 그 양 자체의 변화는 없는 것으로 확인되었다. 그러므로 단순히 보정속옷을 입는 것이 체지방량을 감소 시키지는 않을 것으로 예측할 수 있다. 그러므로 보정속 옷은 압박이 강하더라도 체형보정의 기능만 있을 뿐 체 지방의 저하를 일으키지는 못하는 것으로 확인되었다.

이번 실험에서 이용된 플래시크 사에서 판매하는 보정 속옷은 최대 $3.7 \mathrm{hPa}(27.75 \mathrm{mmHg})$ 의 압박력을 나타낼 수 있다. 이 강도는 기존에 운동선수들에게 착용하여 생리 변화를 측정하였던 연구논문에 이용한 압박 레깅스의 최 대 강도와 비슷한 정도였다. 이 연구논문에서는 $20 \mathrm{mmHg}$ 정도의 중간 압박 정도를 가진 제품이 이 보다 더 높은 압박 강도를 가진 제품보다 효율성이 높은 것으로 보고 되었다. 즉 압박 강도가 어느 수준 이상이 되면 운동 시 효율의 증가가 오히려 감소되는 것으로 나타났다. 이번 실험에서 사용한 보정속옷의 압박 정도가 $18 \mathrm{mmHg}$ 였으 므로 기존에 보고된 연구 결과에서 가장 높은 효율을 나 타냈던 중간 압박 정도의 운동용 레깅스와 유사한 압박 정도였다(Struhar et al., 2018). 그러므로 플래시크 사에서 출시되는 더 높은 압박 강도의 보정속옷의 경우 착용 시 운동효율은 오히려 감소할 것으로 예상된다. 그리고 보정 속옷의 주된 구매층인 중장년 여성의 경우 이번 실험에 참가한 젊은 여자 대학생들에 비해 근육 강도가 평균적 으로 낮을 것이므로, 운동효과보다는 혈압 상승과 폐기능 억제에 따른 단점이 더 있지 않을까 하는 우려가 든다. 그러므로 압박 강도가 $20 \mathrm{mmHg}$ 이상이 되는 제품은 운 동효율의 감소와 생리적 기능의 제한이 더 크게 나타나므 로 장시간 착용이나 운동 시에는 착용을 자제하는 것이 좋을 것으로 판단된다.

보정속옷을 착용하고 운동했을 경우 회복 시에 착용 전보다 더 높이 상승했던 혈압은 오히려 5 분이 경과하면 서 더 낮아지는 현상이 측정되었다. 이러한 혈압 하강과 는 다르게 심박수는 착용한 상태에서 계속 낮게 나타났 다. 이를 통해 신체효율지수(PEI) 값이 높게 나타났다. 심 전도를 통해 확인된 심박수 저하의 원인은 다른 연구 결 
과에서 보고한 것과 일치하게 QT 시간의 증가가 그 원인 이었다(Pruscino et al., 2013; Nguyen et al., 2019). QT 시간은 심실 수축의 시작으로부터 끝날 때까지의 시간을 의미한 다(Song et al., 2018). 심박수가 빨라지거나 느려질 경우 모두 QT 시간의 증감이 주된 원인이 되는 것으로 알려져 있다(Gillett et al., 2014). 이번 실험에서 사용한 QT 시간은 Bazett의 공식으로 수정된 수치 $(\mathrm{QTc})$ 를 이용하였다.

압박 레깅스의 착용은 근육을 지지해줘서 햄스트링 보 호와 근육의 신장이나 수축에 도움이 될뿐만 아니라, 근 육에 산소를 공급하고 운동 후 발생하는 젖산 제거를 활 발하게는 등 생리적인 효과도 있음이 보고되었다(Xiong and Tao, 2018). 이와 유사하게 이번 보정속옷 착용에서도 운동 후 회복에 더 도움이 되는 것으로 나타났다. 이를 통해 움직임이나 무게에 영향을 주지 않는다면 보정속옷 을 착용하고 운동하는 것이 더 나은 효율을 나타낼 것으 로 예측된다.

\section{ACKNOWLEDGEMENT}

This research was supported by Basic Science Research Program through the National Research Foundation of Korea (NRF) grant (http://nrf.re.kr) to D.J (NRF-2019R1I1A3A01061981).

\section{CONFLICT OF INTEREST}

The authors declare that they have no competing interests.

\section{REFERENCES}

Abe T, Kearns CF, Fukunaga T. Sex differences in whole body skeletal muscle mass measured by magnetic resonance imaging and its distribution in young Japanese adults. Br J Sports Med. 2003. 37: 436-440.

Chan V, Duffield R, Watsford M. The effects of compression garments on performance of prolonged manual-labour exercise and recovery. Applied Physiology Nutrition and Metabolism. 2016. 41: 125-132.

da Silva CA, Helal L, da Silva RP, Belli KC, Umpierre D, Stein R. Association of Lower Limb Compression Garments During High-Intensity Exercise with Performance and Physiological Responses: A Systematic Review and Meta-analysis. Sports Medicine. 2018: 48: 1859-1873.

Gillett I, Hillis S, Milne C. Examining the relationship between
QT interval length and heart rate in an athletic population aged 18-25. Scottish Medical Journal. 2014. 59: E32-E32.

Heiss R, Hotfiel T, Kellermann M, May MS, Wuest W, Janka R, Nagel AM, Uder M, Hammon M. Effect of Compression Garments on the Development of Edema and Soreness in Delayed-Onset Muscle Soreness (DOMS). J Sports Sci Med. 2018. 17: 392-401.

Karastergiou K, Smith SR, Greenberg AS, Fried SK. Sex differences in human adipose tissues - the biology of pear shape. Biol Sex Differ. 2012. 3: 13.

MacRae BA, Cotter JD, Laing RM. Compression garments and exercise: garment considerations, physiology and performance. Sports Medicine. 2011. 41: 815-843.

Nguyen LTN, Eager D, Nguyen H. The relationship between compression garments and electrocardiogram signals during exercise and recovery phase. Biomedical Engineering Online. 2019. 18

Pribis P, Burtnack CA, McKenzie SO, Thayer J. Trends in Body Fat, Body Mass Index and Physical Fitness Among Male and Female College Students. Nutrients. 2010. 2: 1075-1085.

Privett SE, George KP, Whyte GP, Cable NT. The Effectiveness of Compression Garments and Lower Limb Exercise on Postexercise Blood Pressure Regulation in Orthostatically Intolerant Athletes. Clinical Journal of Sport Medicine. 2010. 20: $362-367$

Pruscino CL, Halson S, Hargreaves M. Effects of compression garments on recovery following intermittent exercise. European Journal of Applied Physiology. 2013. 113: 1585-1596.

Song JE, Song MJ, Kim YS, Yang HN, Lee YJ, Jung D. Influence of Positional Changes of Arms and Legs to Electrocardiogram. Biomedical Science Letters. 2018. 24: 43-49.

Struhar I, Kumstat M, Kralova DM. Effect of Compression Garments on Physiological Responses After Uphill Running. Journal of Human Kinetics. 2018. 61: 119-129.

Xiong Y, Tao XM. Compression Garments for Medical Therapy and Sports. Polymers. 2018. 10.

https://doi.org/10.15616/BSL.2021.27.2.88

Cite this article as: Jeon SJ, Jung YJ, Lee EJ, Choi JH, Jung D. Wearing of a Whole-Body Compression Garment Can Enhance Exercise Efficiency. Biomedical Science Letters. 2021. 27: 88-94. 